\title{
Determining Prospective Coconut Shell Products using Analytical Hierarchy Process (AHP)
}

\author{
Abidin $^{1}$ \\ ${ }^{1}$ Industrial Engineering, Buddhi Dharma University,Tangerang - Banten, Indonesia
}

\section{SUBMISSION TRACK}

Recieved: February 22, 2021

Final Revision: February 25, 2021

Available Online: March 15, 2021

\section{KEYWORD}

AHP,creative industry, coconut shell

CORRESPONDENCE

Phone: 021-5517853

E-mail: abidin.abidin@ubd.ac.id

\begin{abstract}
A B $\mathbf{S}$ T $\mathbf{R}$ A $\mathbf{C}$ T
Coconut shell is a raw material for creative industrial products to make various products that have artistic value. This study aims to select prospective products from the coconut shell creative industry in Pangandaran Regency using the AHP method. Coco mosaic was chosen as the most prospective product for further development with a priority weight of 0.3339 . Coco mosaic has wide market opportunities, not only in local market but also in the export market. The price of coco mosaic in local market is Rp. $250,000 / \mathrm{m}^{2}$, while in the export market it is US \$27 $40 / \mathrm{m}^{2}$.
\end{abstract}

\section{INTRODUCTION}

Pangandaran Regency is known as the $3^{\text {rd }}$ largest coconut producer in Province of West Java [1]. Ample products are derived from coconut, including foods, beverages, health care and beauty products.

Coconut shell accounts for the major waste of the coconut industries. It is the hardest part of coconut, which protects coconut flesh inside, while outer shell of coconut is coir, which is a fibrous layer.

Coconut shell crafts as art products are popular among creative industries. They can be easily found in places in Pangandaran, being one of the favorite souvenirs for tourists. Crafts from coconut shell vary greatly, such as key holder, cup, bag, lamp shade and coco mosaic.

As a handicraft, coconut shell crafts are expected as a popular souvenir available in tourism spots in the regency, being an alternative to other popular souvenirs such as beach t-shirt, batik, honje syrup, local snacks, virgin coconut oil (VCO), nata de coco, serundeng, galendo, and coconut wood-based products. Other popular products of Pangandaran include coconut sticks, palm sugar, brown sugar, coffee, marinated fish, rattan woven (anyaman hata), as well as various creative stuffs made from clam shells.

Among those products, coconut shell crafts receive the highest interest of tourists. Previous report showed that 50\% of respondents preferred the crafts for their souvenirs in tourism area in Pangandaran [2].

In this work, a research was proposed in order to screen prospective products from coconut shell produced and sold in tourisms in Pangandaran. The prospective product means the selected items potentially able to be improved, regarding their advantageous features.

To determine the product, Analytical Hierarchy Process (AHP) was applied according to expert judgments 
(academicians, practitioners, bureaucrats). The output of this research is useful for stakeholders mainly involved in coconut shell creative industries such as governmental institutions (tourism, industry, local government) and other stakeholders.

\section{METHODS}

Previous studies have been made to select prospective products among items using several methods such as Technique for Order Performance of Similarity to Ideal Solution (TOPSIS) applied to determine the most acceptable coconut-based product in Pangandaran [2], Analytical Hierarchy Process (AHP) carried out to find the prospective coconut agroindustry product [3], Non-Numeric Fuzzy for determining potential apple-derived products [4], as well as Bayes method for selecting prospective products in the integrated coconut agroindustry [5].

In addition, there are also many previous studies related to the decision to choose an alternative. Some of the uses are the use of the AHP method in selecting automotive industry suppliers [6], the use of the Fuzzy AHP method and the Fuzzy Weighted Aggregated Sum-Product Assessment (WASPAS) to select construction sites [7], the use of the Fuzzy AHP and TOPSIS methods to select automotive industry suppliers. [8], as well as the use of AHP models, fuzzy set theory and neural networks to select suppliers for the automotive industry [9].

In this work, AHP was applied to reach research aim. It is common method, enabling to simplify complex, unstructured, strategic and dynamic problems and convert them into structured hierarchy [10]. In AHP, problems could be resolved through hierarchical formation, priority determination and locig consistency.

Stages of research were elaborated as follows:

1. Field observation.

Collecting data about creative products from coconut shells prepared and sold ias souvenirs in tourisms in Pangandaran.

2. Literature study.

Discovering scientific evidence in literatures related to coconut-based industries, decision making process, and methods for selecting the most prospective products.

3. Interview.

Collecting information from experts, relevant stakeholders, merchants, government officers, and visitors.

4. Questionnaire.

Collecting data via questionnaires and comparing in pairs the data from experts such as academician, practitioners and governmental officers (bureaucrats).

Figure 1 illustrates stages of research aiming to find the most prospective coconut shell products of creative industries in Pangandaran. 


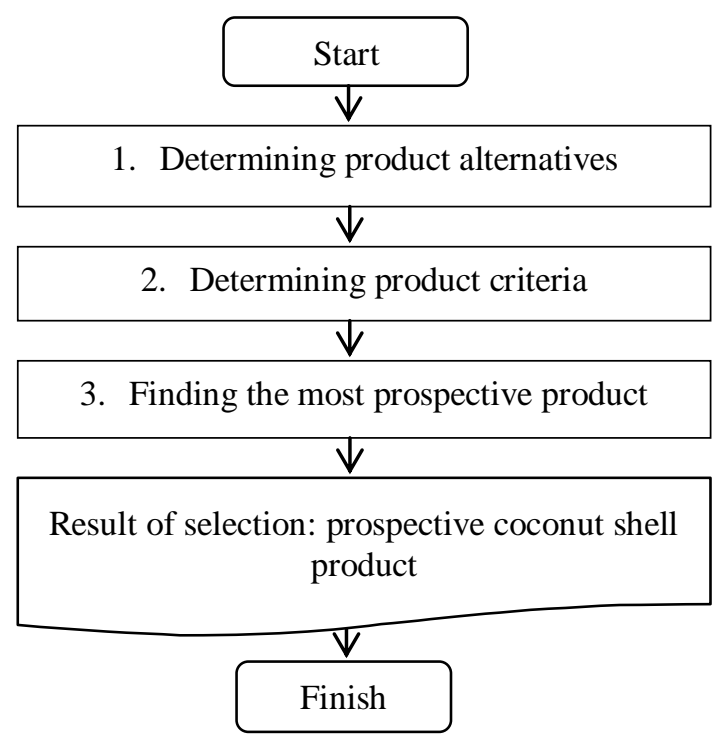

Fig 1:Research Stages

AHP provides advantages as follows [10]:

a. Unity. AHP enables to create a model describing various unstructured issues and dissolve them into easy-tounderstand component.

b. Complexity. To dissolve complex problem, AHP integrates deductive and system-based approaches.

c. Interdependence. AHP can cover element interdependence in a system and not impose linear thinking.

d. Hierarchical Structure. AHP enables to depict natural tendency of minds of decision makers to sort elemts in system at different levels and group similar elements at each level.

e. Measurement. AHP generates a scale for measuring issues and determining priorities.

f. Consistency. AHP can detect logical concistency between considerations or judgments used by decision makers in determining priority.

g. Synthesis. AHP leads to a comprehensive prediction on advantages of each alternative given.

h. Trade Off. AHPprovides chance to reconsider the given alternatives derived from factors as well as suggest the best option regarding the main goal.

i. Judgment and Consensus. AHP does not impose consensus, but creates representative outcome according to judgments.

j. Process Repetition. AHP allows policy makers to redefine issues as response to the emerging problems.

\section{RESULT}

Stages of research (Fig. 1) are elaborated as follows:

1. Product alternative determination.

The alternatives are based on types of existing products in coconut shell creative industries in Pangandaran. They include key holder, cup or glass, spoon, unique bags, lamp shade and coco mosaic. The greatest producer is Saung Kalapa Pangandaran located in District of Parigi, Pangandaran.

2. Criteria determination.

Criteria are set according to interviews with experts (academician, practitioners, bureaucrats) and tourists as consumers. The criteria are uniqueness, price, product manufacture, market.

a. Product uniqueness refers to distinguished features of the product, increasing interest's consumers. 
b. Price is affordable to consumers, but still giving economic benefit to producers.

c. Production refers to the ease of product manufacture process. This relates to technology used, tools and skills of producers.

d. Market means the product's acceptance by visitors not only from local tourists but also foreigners which may buy via online. The product is versatile, for souvenir and other uses such as decoration merchandise and.
In determining product alternatives, questionnaires were distributed using the pairwise comparison concept from Saaty [11]. The questionnaire was distributed to three respondents consisting of academics, bureaucrats, and practitioners. The form of a pairwise comparison questionnaire for the criteria given to experts can be seen in Table 1.Meanwhile, the pairwise comparison questionnaire for alternative products given to experts can be seen in Table 2 .

3. Prospective product determination.

Table 1. Pairwise comparison questionnaire for weighted criteria

\begin{tabular}{lllll}
\hline & Uniqueness & Price & Production & Market \\
\hline Uniqueness & & & & \\
Price & & & \\
Production & & & \\
Market & & & \\
\hline
\end{tabular}

Table 2. Pairwise comparison questionnaire for product alternative weighting

\begin{tabular}{|c|c|c|c|c|c|}
\hline & Key holder & Lamp shade & $\begin{array}{l}\text { Household } \\
\text { utensils }\end{array}$ & Bag & Coco mosaic \\
\hline \multicolumn{6}{|l|}{ Key holder } \\
\hline \multicolumn{6}{|l|}{ Lamp shade } \\
\hline \multicolumn{6}{|c|}{ Household utensils } \\
\hline \multicolumn{6}{|l|}{ Bag } \\
\hline Coco mosaic & & & & & \\
\hline
\end{tabular}

Furthermore, to select a prospective product for the coconut shell creative industry, the problem is formed in the AHP structure, namely in a hierarchy of problems as shown in Figure 2. Based on this hierarchy the experts are asked to provide an assessment of each alternative and given criteria. Expert judgment is then measured for consistency using consistency ratio (CR), which is acceptable at CR of $<10 \%$ [10]. CR is calculated as follows:

$$
\mathrm{CR}=\frac{\mathrm{CI}}{\mathrm{RI}}
$$

where:

$\mathrm{CR}=$ Consistency Ratio

$\mathrm{CI}=$ Consistency Index

$\mathrm{RI}=$ Random Index
When the judgments meet the criteria of $\mathrm{CR}$, they are then aggregated. Aggregation is required since the judgment comes from 3 expert groups. Formula for aggregation is presented below:

$N_{G}=\sqrt[e]{N_{1}(i j) x N_{2}(i j) x \ldots x N_{e}(i j)}$.

where:

$\mathrm{N}_{\mathrm{G}} \quad$ = Aggregation matrix

$\mathrm{N}_{\mathrm{e}}(\mathrm{ij})=$ Score given by expert-1 to $e$

$e \quad=$ Number of experts

After aggregation, weight for each criteria and alternatives is set according to AHP and sorted based on priority to find prospective product in coconut shell creative industries. Fig. 2 depicts AHP structure of this study. 


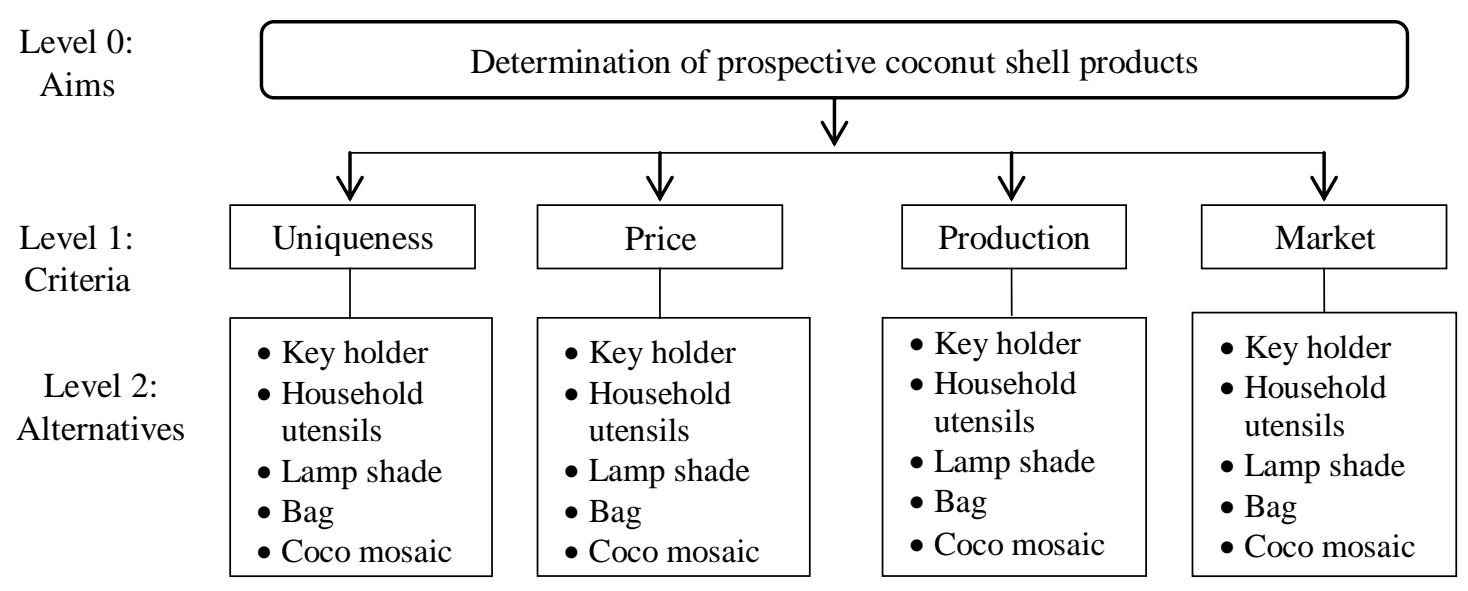

Fig 2: Structure of AHP for selecting prospective coconut shell products

Based on the results of data processing using the AHP method, the final weight for the prospective product selection criteria for the coconut shell creative industry is obtained as shown in Table 3 below.

Table 3. Final weight for each criterion

\begin{tabular}{cc}
\hline Criteria & Final Weight \\
\hline Uniqueness & 0.2571 \\
Price & 0.2713 \\
Production & 0.1352 \\
Market & 0.3364 \\
\hline
\end{tabular}

As presented in Table 3, final weight for market potential is 0.3364 , being the major priority of coconut shell products. This is understandable as market relates to flexibility and certainty of product selling; thus, it receives the highest score. The selected needs to receive high and wide consumer's acceptance, which reduces marketing barriers.
On the other hand, the lowest weight corresponds to production criterion, i.e. 0.1352. commonly, techniques for manufacturing products are teachable, strengthened by effective training given by counterparts. For this reason, the techniques can be promptly transferred to craftsman.

Further step is final weight determination of each alternative product based on criteria, as presented in Table 4.

Table 4. Weight for each alternative product by criteria

\begin{tabular}{ccccc}
\hline & & & \\
Criteria & Uniqueness & Price & Production & Market \\
\hline Key holder & & & & \\
Lamp shade & 0.1643 & 0.0514 & 0.2324 & 0.3247 \\
Household utensils & 0.1253 & 0.1511 & 0.2635 & 0.1972 \\
Bag & 0.0891 & 0.0612 & 0.1965 & 0.0183 \\
Coco mosaic & 0.2542 & 0.3221 & 0.1753 & 0.2016 \\
& 0.3671 & 0.4142 & 0.1323 & 0.2582 \\
\hline
\end{tabular}

From Table 4, coco mosaic receives the first place in terms of product uniqueness compared with other products. Similarly, the highest score for price is also attributed to coco mosaic. However, spoon (household utensils) possesses the highest score in production criterion. Regarding market prospect, key holder is on the first rank.

Last, among product alternatives, the most prospective one is determined according to criteria. The result of this stage is presented in Table 5 . 
Table 5. Priority weight for alternatives of coconut shell products

\begin{tabular}{|c|c|c|c|c|c|c|c|}
\hline Criteria & Uniqueness & Price & Production & Market & & $\begin{array}{c}\text { Weight } \\
\text { of } \\
\text { Criteria }\end{array}$ & $\begin{array}{c}\text { Weight } \\
\text { of } \\
\text { Priority }\end{array}$ \\
\hline Key holder & 0.1643 & 0.0514 & 0.2324 & 0.3247 & & 0.2571 & 0.1745 \\
\hline Lamp shade & 0.1253 & 0.1511 & 0.2635 & 0.1972 & & 0.2713 & 0.1752 \\
\hline Household utensils & 0.0891 & 0.0612 & 0.1965 & 0.0183 & $\mathrm{x}$ & 0.1352 & 0.0722 \\
\hline Bag & 0.2542 & 0.3221 & 0.1753 & 0.2016 & & 0.3364 & 0.2443 \\
\hline Coco mosaic & 0.3671 & 0.4142 & 0.1323 & 0.2582 & & & 0.3339 \\
\hline
\end{tabular}

\section{DISCUSSION}

Prospective product selection is based on the greatest value of priority weight. The priority weight is obtained from the accumulated multiplication value between each alternative product with all the weight of the criteria. In other words, the selected prospective product is the product that has the highest priority weight from the calculation results that have considered all the criteria used.

As presented in Table 5, priority weight for coco mosaic is the highest, i.e. 0.3339, followed by bag (0.2443), lamp shade (0.1752), key holder (0.1745) and household utensils (0.0722). This suggests that coco mosaic is selected as the most prospective coconut shell product.

When compared with other product alternatives, for example key holder, from the preliminary calculation results, coco mosaic has the highest weight of price and uniqueness criteria. These two criteria have the second and third largest weight after the market criteria. Therefore, even though in terms of market criteria, the key holder has the highest value, but the final calculation result of priority weight ranks third. Therefore, coco mosaic was chosen as the most prospective product.

Information collected through an interview with owner of Saung Kalapa Pangandaran suggests that coco mosaic provides a tremendous economic value since it has a wide market, not only sold in tourism spots, but also developed for export as decorative materials in office, house and hotel. The product can be produced through partnership system, which means that the craftsman may come from other regencies, enabling to meet the demand. Coco mosaic is produced in two major steps. First, the single pieces with particular shape and size are made by local craftsman in many creative industries of Pangandaran, while the final mosaic is then assembled in other sites such as Cirebon.

Coco mosaic has an affordable price and wide opportunity for export. The price reaches Rp. $250.000 / \mathrm{m}^{2}$ for domestic marker and US\$ $27-40 / \mathrm{m}^{2}$ for international market depending on difficulties. It is now exported to various countries, including US, South Korea, France, Poland, South Africa, Malaysia and Singapore [12]. Fig. 3 displays the example of coco mosaic as wall decoration, produced by PT. Java in Cirebon. This company receives raw pieces from Pangandaran.

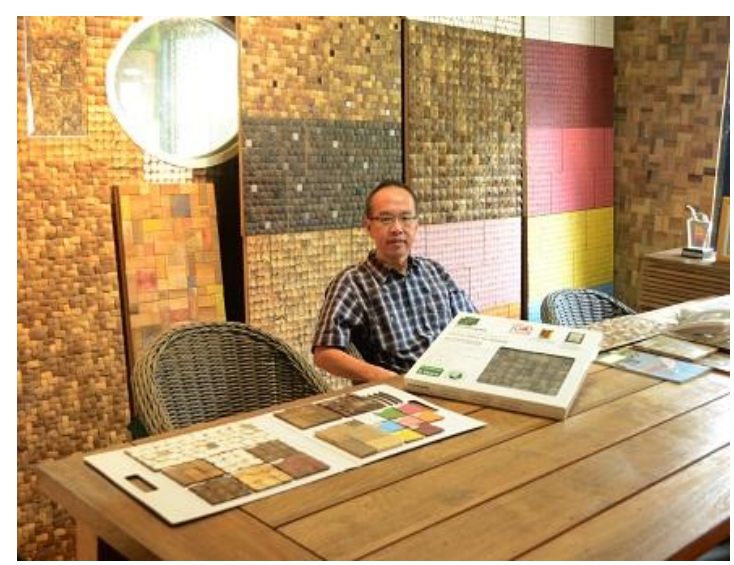

Fig 3: Display of coco mosaic applied as wall decoration developed by PT. Java Cirebon [12]

\section{CONCLUSION}

The research concluded that coco mosaic shows the most prospective coconut shell product in Pangandaran, with priority weight of 0.3339. It can be marketed not only as souvenir in tourism spots of Pangandaran and other regencies but also as high valuable export product. The price is Rp. $250.000 / \mathrm{m}^{2}$ for domestic market, but for export it may range US\$ $27-40 / \mathrm{m}^{2}$, demanded in various 
countries, including US, South Korea, France, Poland, South Africa, Malaysia and Singapore. Coconut shell creative industries in
Pangandaran have partnership scheme with coconut shell industries in Cirebon.

\section{REFERENCES}

[1] Abidin, "Formulasi Strategi Pengembangan Agroindustri Kelapa di Pangandaran Melalui Pembiayaan Partnership Bebas Bunga", Ph.D thesis, Sekolah Pascasarjana, Institut Pertanian Bogor, Bogor, Indonesia, 2020.

[2] Abidin, Sukardi, D. Mangunwidjaja, and M. Romli, "Potensi Agroindustri Berbasis Kelapa untuk Pemberdayaan Ekonomi Masyarakat di Kabupaten Pangandaran - Jawa Barat”, Jurnal Teknologi Industri Pertanian, Vol. 28, No. 2, 2018, p. 231-243.

[3] Abidin, "Pemilihan Strategi Hijau (Green Strategy) Pengembangan Agroindustri (Studi Kasus: Agorindustri Berbasis Kelapa)", Jurnal Akselerator, Vol. 3, No. 1,2018, p. 1-13.

[4] I. Santoso, and Marimin, "Penentuan Produk Olahan Apel Unggulan Menggunakan Teknik Fuzzy Non Numerik dan Analisis Struktur serta Pola Pembinaan Kelembagaannya", Jurnal Teknologi dan Industri Pangan, Vol. XII, No. 2, 2001, p. 163-170.

[5] B.D. Probowati, Y. Arkeman, and D. Mangunwidjaja. "Penentuan Produk Prospektif Untuk Pengembangan Agroindustri Kelapa Secara Terintegrasi”, Fakultas Pertanian, Universitas Trunojoyo, Madura, Indonesia, 2011.

[6] F. Dweiri, S. Kumar, A.A. Khan, and V. Jain. "Designing an Integrated AHP Based Decision Support System for Supplier Selection in Automotive Industry”, Expert System with Applications Journal, Vol. 62, 15 November 2016, p. 273-283.

[7] Z. Turskis, E.K. Zavadskas, J. Antucheviciene, and N. Kosareva. "A Hybrid Model Based on Fuzzy AHP and Fuzzy WASPAS for Construction Site Selection", International Journal of Computers Communications and Control, Vol. 10, No. 6, 2015, p. 873-888.

[8] V. Jain, A.K. Sangaiah, S. Sakhuja, N. Thoduka, and R. Aggarwal. "Supplier Selection Using Fuzzy AHP and TOPSIS: A Case Study in The Indian Automotive Industry", Neural Computing and Applications, Vol. 29, 24 August 2016, p. 555-564.

[9] A.K. Kar. "A Hybrid Group Decision Support System for Supplier Selection Using Analytic Hierarchy Process, Fuzzy Set Theory and Neural Network", Journal of Computational Science, Vol. 6, January 2015, p. 23-33.

[10] Marimin, Sistem Pendukung Pengambilan Keputusan dan Sistem Pakar, Bogor: IPB Press, 2017.

[11] T.L. Saaty, Decision Making for Leaders: The Analytical Hierarchy Process for Decision in Complex Word, Pittsburgh: RWS Publication, 1988.

[12] SWA, "Ferry Tandean, Eksportir Mebel Cocomosaic ke 20 Negara", [internet], [referred to 12 February 2021], available from: https://swa.co.id/swa/profile/profileentrepreneur/ferry-tandean-eksportir-mebel-cocomosaic-ke-20-negara.

\section{BIOGRAPHY}

Abidin, completed his B.Sc degree in Department of Industrial Engineering from Institute of Science and Technology Al Kamal, Jakarta in 1998. He received M.Sc degree in Agro industrial Technology from IPB University in 2003 and Ph.D in Agro industrial Engineering from IPB University in 2020. He currently works as a lecturer in Department of Industrial Engineering, Buddhi Dharma University. 